\title{
The Political Communication Strategy of the Presidential Campaign Team Jokowi-Ma'ruf Amin to Win the Support of the Ummah Islam in the 2019 Election in North Sumatra
}

\author{
Hasyimsyah Nasution', Syukur Kholil ${ }^{2}$, Muhammad Idris ${ }^{3}$ \\ ${ }_{1,2,3}$ Universitas Islam Negeri Sumatera Utara, Indonesia
}

\begin{abstract}
This study aims to analyze the communication patterns of President Jokowi-Ma'ruf's campaign team in the 2019 elections in North Sumatra, the communication management of the campaign team, the response of the voters, and the results achieved by the campaign team. The data sources consisted of primary data, namely from the North Sumatra regional campaign team and secondary data from various books, documents, journals, articles, websites and others related to this research. The main informants were the campaign team which was determined purposively in accordance with the research objectives. Besides that, the community also distributed questionnaires to the voters for the Jokowi-Ma'ruf Amin presidential candidate in several cities and districts, namely Medan, Tebing Tinggi, Simalungun, and Tapanuli Tengah as a form of representation from the regions in North Sumatra because of the diversity of ethnicities, cultures, and religion. The results of the study indicate that the communication pattern of President Jokowi-Ma'ruf Amin's regional campaign team in North Sumatra is carried out in broad lines through two forms, namely direct communication with the community and indirect communication or by using mass media. The delivery of infrastructure development work programs to the campaign masses received a response from the voting public. Campaigns through the approach and involvement of religious leaders can also attract sympathy from the voters. The voters for the Jokowi-Ma'ruf presidential candidate in North Sumatra generally answer because of the figure of the presidential candidate. Meanwhile, the position of Kiyai Haji Ma'ruf Amin as a vice presidential candidate is a factor that can influence or increase the electability of Muslims in determining the victory of a presidential candidate.
\end{abstract}

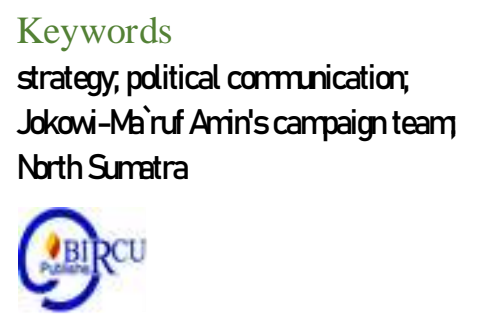

\section{Introduction}

Democracy is a brilliant idea that changes the politics of the world. The emergence of democracy is something that is considered important because it is a political idea containing values that are needed as a reference for managing the life of the nation in a country. In elections, citizens can give their voting rights both in the form of voting rights and the right not to vote. As a process and quality of democratic life in this country, legislative elections deserve the support of all the people of Indonesia. Not only is the function of elections to elect legislative representatives and or national leaders, but also because the election itself carries a substantial moral message so that the people elect people's representatives who have a conscience. (Rozaili, 2020)

Democracy has become a central issue in the past decade related to the dynamics of social change and Indonesian state administration. People have high hopes for improvement 
as a result of the development of democracy in Indonesia, especially in the era of modernization. Indonesia, which is classified as a developing country in Southeast Asia, has resulted in many developments from the outside world who want to enter Indonesia or even force them to enter Indonesia. the modernization era which is marked by the rapid development of information and technology resulting in an increase in one's curiosity about various forms of information. This makes it seem as if the world without borders is the door to open windows, this term is known as globalization. Influences originating from the western world bring all negative and positive impacts. The rapid development among the people of Indonesia shows various developments. Starting from clothing fashion trends, lifestyles, and social order those changes with the emergence of a social gap in the social environment. (Prasetyo, 2020)

Democracy puts pressure on the largest number of votes of the people to get the right to run the country. In 2019, the implementation of general elections (elections) is carried out simultaneously, namely the general election of legislative member candidates, candidates for members of the Regional People's Representative Council (DPRD), the People's Representative Council (DPR), and the Regional Representative Council (DPD) as well as the election of Presidential Candidates. And the Vice President which took place April 17, 2019. This is in accordance with the Election Law no. 7 of 2019. Interestingly, the hot issue of the election for Presidential and Vice-Presidential candidates for the 2019-2024 period defeated the issue of electing legislative candidates.

This can be seen from the enthusiasm and concentration of the people who are more focused on the presidential candidates who will fight in the presidential election compared to the election of candidates for legislative members (caleg). The public as voters are often treated to information regarding the two competing presidential candidates. This almost makes people's memories of the 2019 election only a moment for the presidential election.

The competition to win the people's votes was only followed by two candidate pairs, namely President Joko Widodo - Ma'ruf Amin (incumbent) who competed with presidential candidate pair Prabowo Subianto - Sandiaga Uno. The determination of the two pairs of candidates was after the General Election Commission (KPU) issued a KPU decision No: 1131 / PL.02.2-KPT / 06 / IX / 2018 concerning the determination of presidential and vice presidential candidates for the 2019 general election.

For any campaign team or winning body, the goal of the campaign is to win. How is the strategy designed to succeed in bringing candidate pairs who are brought into positions that are contested through the direct election mechanism by the people. Election is a means for the people to choose a leader who is considered capable of bringing progress to the people, nation and state. The moment of the correct election, determines the future of the nation, progress, and the welfare of the Indonesian people in the future.

North Sumatra Province is one of the largest provinces in Indonesia. Many people mention the North Sumatra region as a barometer of success. In the area of ethnic and ethnic diversity inhabited by multiple tribes. The population of various tribes such as Javanese, Batak, Padang, Minang, Banjar. Meanwhile, religion, Islam, Christianity, Buddhism, Hinduism. Even though there are various ethnic groups, based on the 2010 population census data (BPS RI), the Muslim population in North Sumatra is 8,579,830 people (68\%).

Looking at the voter map, the two competing candidates tried to attract the ulama in their respective ranks. The ulama's representation was contested by the two candidates because it was considered to be able to attract Muslim votes. President Jokowi first collaborated with the ulama by making Ma'ruf Amin, who was the chairman of the MUI, as his deputy. The Prabowo-Sandi pair received support from the Ulama Fatwa Guard National 
Movement (GNPF) through the Ijtimak Ulama II forum. Muslims consider the ulama to be the leader of the ummah, so that the role of the ulama is very large in determining the choice of Muslims in the 2019 presidential election.

Executive Director of the Indonesia Political Review (IPR), Ujung Komaruddin, assessed that the struggle for the representation of the ulama between the two candidates was inseparable from the desire to win over Muslim voters in Indonesia. The percentage of Muslim voters is very large, predicted around $85-90 \%$ of all existing voters.

Muslims consider the ulama to be the leader of the ummah, so the role of the ulama is very large in determining the choice of Muslim ummah in the 2019 Election. The power of representation of ulama in politics has been proven through the 2917 DKI Regional Election. At that time Anis Baswedan-Sandiaga Uno was able to win the contest against Basuki Tjahaya Purnama (Ahok) -Djarot Syaiful Hidayat. Anis-Sandi's victory cannot be separated from the 212 movement which was supported by the ulama.

\section{Review of Literatures}

In communication science, in terms of its delivery, both the media and the method are divided into two parts, namely direct communication and indirect communication. In general, the pattern of political communication carried out by the Jokowi-Ma'ruf campaign team in North Sumatra is a pattern of communication directly with the community and indirectly with using media.

\subsection{Direct Communication}

Direct communication carried out by the Jokowi-MA campaign team in North Sumatra, in the form of meetings with voters, hands-on operation to crowded places, and door-to-door meetings conducted by regional campaign teams and volunteers in North Sumatra. The market is one of the locations for President Jokowi-MA's hands-on operation in during the campaign. Hands-on operation not only comes, but also communicates in two ways with the local community directly.

The President Jokowi-Ma'ruf Campaign Team in North Sumatra visited the community with the success team and volunteer teams to help communicate their political communication strategy to all levels of society. The campaign team held meetings with community and religious figures such as clerics, clerics, preachers and social figures. Several activities in the 2019 Election campaign were the implementation of the political communication strategy of the Jokowi-MA pair campaign team in North Sumatra

\subsection{Indirect Communication Patterns}

The indirect communication pattern carried out by the Jokowi-MA campaign team in North Sumatra has been impractical, the communication carried out using the mass media. Both conventional mass media (meinstrem media) and alternative media (social media). Because the media is considered important, there is a special team provided by the campaign team in managing the media.

Online media is one of the media to reach young voters. The message conveyed to the voting community is the work program that has been carried out and the further perfection of the work program. The most frequently used social media (medsos) such as online media, fecebooks, twiter, WA group. Following then conventional mass media such as television, newspapers, and others. Besides that, it is also used, the use of outdoor media, such as the installation of banners, billboards, billboards, T-shirts, marcines, and others. The use of 
media coverage is the best way to build a good image in the eyes of the public which in turn can influence voter behavior.

\subsection{Lasswell Formula Communication Patterns}

Communication patterns can be interpreted as a form or pattern of relationship between two or more people, in the process of sending and receiving messages in an appropriate manner so that the message in question can be understood structure) which is fixed.

Communicators use the media because the communicants who are targeted for communication are far away or there are many or both, far and wide. Communication in this secondary process is increasingly effective and efficient because it is supported by increasingly sophisticated communication technology, which is also supported by other technologies that are not communication technology.

Laswell's communication pattern involves five components of communication which include who, Say what, in what channel, to whom, what effect. Thus Laswell's communication pattern involves five interrelated communication elements, namely: communicator, message, media, communicant and effects. These five Laswell basics provide a useful way of analyzing communication. Laswell's communication pattern is described as follows.

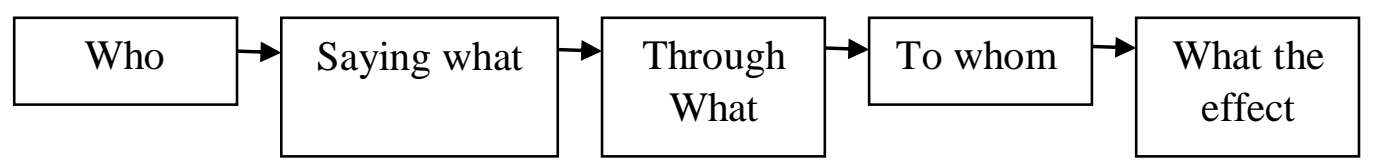

Figure 1. Secondary Communication Patterns Source: Lasswell

\section{a. Political Communicators}

The first element in the communication pattern according to Lasswell's formula is the communicator. Communicators are meant to be people who convey messages to listeners (communicants). Communicators in this case are political communicators or the campaign team.

Judging from the structure of the Jokowi-MA campaign team in North Sumatra, it is filled with political actors, community leaders and businessmen. This included a number of names of mayors and regents in North Sumatra as well as administrators from each of the 9 supporting parties who dominated the campaign team structure. Apart from the campaign teams that were formed in 33 districts / cities in North Sumatra, volunteer teams were also formed to help the campaign teams.

Mass politics is politics that is awakened on the basis of pragmatic and opportunist ideologies. Massive intimidation and mass mobilization accompanied by money politics and imagery are characteristics of mass politics. In mass politics the potential for conflict is also quite high. It is not uncommon for people to become victims. (Iryadi, 2019)

\section{b. Political Message}

A political message is a statement conveyed, either in writing or not in writing, either verbally or non-verbally, secretly or openly, whether consciously or unconsciously, the content of which contains political weight. For example political speeches, party laws, election laws, political statements or the contents of books / brochures and news from newspapers, radio, television and the internet, which contain political commentary, propaganda, psychological warfare (psywar), the meaning of logos, color of clothes or flags, body language, and other similar things. 
Political communication carried out by the campaign team and all winning teams and volunteers, which aims to create positive public opinion on the supported presidential candidates. Various kinds of work programs and achievements are disclosed to serve as political marketing. Of course, many policies have been launched to attract and influence voter behavior.

The work programs offered are in the form of continuing development such as free education and health, pre-employment cards, smart cards, and toll road infrastructure development.

Campaign themes are national and regional. The theme of the national campaign, such as economic growth, education, goog government, corruption eradication, electronic public services, was conveyed by Jokowi in the campaign in each region. Then the regional campaign team describes what is the vision and mission and work program of the president according to the region.

The theme of the regional campaign is like raising local regional issues, because each region has different local issues. North Sumatra, for example, is a local issue concerning agrarian issues, labor, the construction of the Medan-Tebingtinggi toll road, and the construction of the Pematang Siantar, Binjai toll road and others will be carried out.

National themes such as how Indonesia's life is diverse, different ethnicities, religions, tolerance and mutual respect. Campaign themes do not antagonize religious issues, but a tolerant life. A life of mutual respect between religious communities. Ideologically, Indonesia is Pancasila within the Unitary State of the Republic of Indonesia. Jokowi with his slogan work ... work ... work, not making promises, but works so that development can proceed. That is what the campaign team and volunteers always say about it.

\section{c. Political Channels}

Political channels or media are the means used by communicators in conveying their political messages. The mass media used in the campaign are of two types, namely media meinstreim or mainstream media and social media (medsos). Meinstrem media such as television, newspapers are considered effective in disseminating work programs. Then social media, as an alternative media, is the media most often used because of the extraordinary technological developments and its considerable influence, especially for social media users such as melinials, middle society, housewives, and even the use of social media has reached remote villages.

The influence of social media, whether it's Facebook, Instagram, WhatsApp (WA) group, is used to convey positive things about the vision and mission and work programs. The campaign team also used outdoor media such as billboards, banners, billboards, t-shirts, marches, logos. Various media as long as they give effect are used as a means of communication to voters or the public in North Sumatra. All of these media are used in parallel (at once). Is it the social media, social media, outdoor media, because each of these media has the same intersecting segment, even though it has different characters.

\section{d. Political Goals or Targets}

The target is the community that is expected to provide support in the form of voting for parties or candidates in general elections or political parties. They are constituents or people who already have a voice to participate in exercising their political rights who already have the right to vote, namely those who are 17 years old or already married. All of them become political targets or targets as communicants who must be seized by their sympathy and choice. 
Prior to the campaign, the Jokowi-MA campaign team in North Sumatra conducted research or surveys. This becomes the basis of strength for the discretionary community of voters. This was done with the aim of photographing potential areas or areas. By conducting surveys and mapping, we know which areas are base areas, which areas are weak, and which areas need to be improved.

The approach to Muslim voters is clear, because the population of North Sumatra Province is the majority of Muslims. This condition is mapped geographically, where the North Sumatra region is mapped into two areas, namely the West Coast and the East Coast region.

West Coast areas such as Karo, Simalungun, Siantar, Tapanuli Nias, and others. Meanwhile, the East Coast areas include the City of Medan, Langkat, Binjai, Asahan, Labuhan Batu, Tabagsel, and other areas. Generally the East Coast region is the majority of Muslim voters and the region is considered to gain the most votes, the most significant voters. So an approach and hands-on operation was carried out to Muslim voters through the approach of mass organizations, ulama, ustad in the area.

\section{e. Election effects / results}

From the tabulation of the total votes acquired by the presidential candidates from regencies / cities in North Sumatra, the pair number 01 Jokowi-Ma'ruf is narrowly superior to their rivals with the acquisition of: 3,838,749 (52.16\%) votes, rival pair number 02 PrabowoSandi received 3,520,846 (47.84\%) votes.

For the entire East Coast, the Prabowo-Sandi pair were superior with total votes: 3,168,384 (59.22\%) and Jokowi-MA: 2,181,838 (40.78\%) votes. For this region, the vote acquisition is a thin difference for the City of Medan and the regencies / cities that are close to Medan City, but it is increasingly far from Medan City areas such as Labuhan Batu, Tabagsel, the difference in the defeat of Jokowi-MA's votes is getting bigger. On the other hand, for the entire West Coast, the Jokowi-MA pair won handsomely with the acquisition of: 1,656,911 (82.46\%) votes and Prabowo-Sandi: 352,462 (17.54\%) votes.

\section{Discussion}

\subsection{Campaign Team Management}

Communication management is how people manage the communication process in relation to other people in the context of communication. Literally, management is the science of completing work through planning, organizing, controlling and leadership.

The management of the Jokowi-Ma'ruf Team campaign in North Sumatra, along with the entire winning team and volunteers, aims to plan a victory for the presidential candidates who are supported. Management of the campaign team includes mapping, consolidation, delivery of work programs, and approaches of religious leaders.

\section{a. Mapping}

Before the campaign is carried out, of course, research or survey is carried out. This becomes the basis of strength for the discretionary community of voters. This was done with the aim of photographing potential areas or areas. By conducting surveys and mapping, find out which areas are base areas, which areas are weak or areas that are still gray, which areas should still be maintained and which areas need to be improved.

In the context of the campaign, this area was mapped so that it could get significant votes for the Jokowi-Ma'ruf pair, because it was known that the majority of the voters on the east coast were Muslim. Although it is not easy, the approach is prioritized to win Muslim 
votes, so a communication approach is made to religious leaders, community leaders, religious scholars, clerics, Islamic organizations to get the support of Muslim voters. Therefore we take the approach by doing hands-on operation -hands-on operation .

Generally the East Coast region is the majority of Muslim voters and the region is considered to have the most votes, the most significant voters. So an approach and hands-on operation was carried out to Muslim voters through the approach of mass organizations, scholars, clerics in the area. Although this is not easy to do because the issue of identity politics is getting stronger ahead of the election.

\section{b. Consolidation}

Regional campaign teams (TKD) are present in 32 City Districts in North Sumatra with volunteer teams and 9 supporting parties each, starting from PDIP, Nasdem, Golkar, Hanura, PPP, which consolidate both internally and externally.

Consolidation in politics is an activity carried out to strengthen and unite several political forces in order to become one tight and solid unity. Especially in the face of political momentum such as the 2019 Presidential Election. Through a close and solid relationship, each party will carry out an internal strengthening process towards running the party machine optimally. Each political party as well as candidate members of the legislature (caleg) from each supporting party are required to campaign for the presidential candidate in addition to campaigning for themselves and their parties.

\section{c. Approach of religious figures}

Most campaign activities are carried out by the door to door method or door-to-door visits by mobilizing 50 to 100 people. This strategy was carried out with the regional campaign team to convey the work program of the Jokowi-Ma presidential candidate, ruf in North Sumatra. From the campsite visit, an approach was made to the owner of the house, and then conducted limited meetings with the Koran recitation groups, and the pesantren.

Campaign strategies like this are mostly carried out in East Coast areas such as Medan, Deliserdang, Serdang Bedagai, Labuhan Batu, and other areas that are generally Muslimmajority voters. The approach strategy is being touched, cared for, and taken away. Meanwhile, the West Coast regions such as Karo, Dairi, Tapanuli and other areas are not too marginalized, because based on the analysis, they tend to choose candidate number 01, and some volunteers come from the West Coast region. There are not many work programs in the West Coast region. The regional campaign team work programs are more focused on the East Coast region.

In this area, campasing and limited meetings were conducted with community groups together with the regional campaign team and the volunteer team. Volunteer teams always coordinate and are strengthened by regional campaign teams. Which one is still empty, volunteers are encouraged to move there. Approach to characters who can be approached, although some cannot. Approach to recitation groups, officers, pesantren and others. Approaches were also made to mass organizations such as Alwasliyah and Muhammadiyah. Meanwhile, NU has clearly supported it. Approaches were also made to groups of laborers, fishermen and NGOs. Each volunteer and the campaign team have their own approach.

The approach strategy is carried out according to the character of each volunteer. There are volunteers logically strong enough to be able to present national class religious figures such as Hadda Alwi. Then there are volunteers who specifically approach millennials, hold music competitions in cafes, etc. Volunteers also carry out mapping such as field surveys, such as Kelurahan Medan Johor for example, this area does not need to be attacked because 
there are many realists from there. The regional campaign team carried out the mapping at the district level, while volunteers did the mapping at the sub-district and kelurahan levels.

In accordance with the field, character, and work program of each volunteer team, there are those that focus on general, religious, sectoral, professional, farmers, fishermen, women, and other issues. As with the volunteer "Jamila" specifically targeted at Muslim mothers. Ma'ruf Amin volunteers, especially their approach to Muslim voters. However, in percentage, 80 percent of volunteers are general, 15 percent are religious and the remaining 5 percent are sectoral, such as farmers, fishermen, women and others.

\section{d. Work program}

Of course, many policies have been launched, and this is a value in itself to attract and influence voter behavior. The work program that was delivered gave hope for a better development, especially continuing free education and health, pre-employment cards, smart cards, and toll road infrastructure development.

The infrastructure development work program in North Sumatra has really been carried out, the economic development of people who are on the poverty line. The Healthy Indonesia Card, Smart Indonesia Card, PKH were conveyed and buzzed during the presidential election campaign yesterday. This is also conveyed when visiting the community and its citizens. From the results of observations and interviews with the campaign team, the following researchers describe the results of the analysis of the political communication strategy of the presidential candidate campaign team number 01 for the Jokowi-Ma'ruf pair in North Sumatra.

Table 1. Team Political Communication Strategy Analysis President Jokowi-Ma'ruf Amin's Campaign in North Sumatra

\begin{tabular}{|c|c|c|c|}
\hline No. & \begin{tabular}{|c|}
$\begin{array}{c}\text { Communication Strategy } \\
\text { Political }\end{array}$ \\
\end{tabular} & Indicator & Realization \\
\hline 1. & Communication Patterns & $\begin{array}{l}\text { 1. Direct } \\
\text { Communication } \\
\text { 2. Indirect } \\
\text { Communication } \\
\quad \text { a. Defensive and } \\
\quad \text { Offensive } \\
\end{array}$ & $\begin{array}{l}\text { - Open campaign } \\
\text { - Prick } \\
\text { - Door to door/ camp } \\
\text { - Using mass media } \\
\text { - Social media } \\
\text { - Outdoor media } \\
\end{array}$ \\
\hline 2. & $\begin{array}{l}\text { Communication } \\
\text { Management }\end{array}$ & $\begin{array}{l}\text { 1. Mapping } \\
\text { 2. Consolidation } \\
\text { 3. Approach of } \\
\text { religious figures } \\
\text { 4. Work program }\end{array}$ & $\begin{array}{l}\text { - Campaign Team and Volunteers } \\
\text { - East Coast Region and West Coast } \\
\text {-Ulama, ustad, Islamic organizations. } \\
\text {-Development of toll road } \\
\text { infrastructure, diversity, tolerance, } \\
\text { NKRI, etc. }\end{array}$ \\
\hline 3. & Muslim voter support & $\begin{array}{l}\text { 1. Involving } \\
\text { religious leaders } \\
\text { 2. CBO approach }\end{array}$ & $\begin{array}{l}\text { - Ustad, Ulama, Dai, etc. } \\
\text { - Ormas NU, Alwasliyah, } \\
\text { Muhammadiyah }\end{array}$ \\
\hline 4. & The results achieved & $\begin{array}{l}\text { 1. East Coast Region } \\
\text { 2. West Coast } \\
\text { Region }\end{array}$ & $\begin{array}{l}\text { - Almost all regions } \\
\text { lost, but not badly } \\
\text { - Win hands down. }\end{array}$ \\
\hline
\end{tabular}

Source: Researcher 


\subsection{Voter Response}

From the tabulated data on respondents' answers distributed to 120 respondents to voters for the Jokowi-Ma'ruf Amin presidential candidate through a questionnaire related to the campaign team's strategy and the response of the voters to the candidates in North Sumatra, it can be interpreted as follows:

The hands-on operation visit of the presidential candidate campaign team in North Sumatra influenced or increased the confidence of the voters for the presidential election. Delivery of work programs such as building toll road infrastructure during campaigns has an effect or increases the confidence of voters for the presidential candidates. The use of outdoor media such as billboards has an effect or increases the confidence of voters.

Campaigns by approaching and engaging with religious leaders, clerics, clerics, and others to get the support of Muslim voters. The Jokowi-Ma'ruf Amin pair are the presidential candidates who campaign the most compared to the Prabowo-Sandi pair. From the delivery of work programs in the form of Smart Indonesia Cards (KIP), Healthy Indonesia Cards (KIS) delivered by the North Sumatra campaign team had an effect or increased confidence in choosing.

Jokowi-MA voter respondents answered that they chose because they were interested in the figure of the presidential candidate. Voters answered that they were interested in the presidential candidate's work programs such as toll road infrastructure development. The dominant voters answered that they were interested in choosing the presidential candidate by involving religious figures such as clerics and clerics in the campaign team.

Ma'ruf Amin's position as vice president influenced or increased the electability of Muslims in the 2019 elections. Voters answered that their chosen presidential candidate had the ability to lead the country. The factors that are considered the most influential on the choice of respondents are dominated by work program factors. According to respondents, the 'incumbent' position factor was a factor in the victory of the Jokowi-MA presidential candidate in the 2019 presidential election.

Respondents to the Jokowi-MA presidential candidate voters for each of the question items above were very high, reaching $70-90 \%$.

Then following the respondent's answer about the use of mass media most often used by respondents is television, while outdoor media is billboards. Online media according to the response is more effective than other mass media for campaigns. Campaign by doing door to door. Respondents to the Jokowi-MA presidential candidate voters for each of the question items above reached 50-69\%.

While economic factors are the more dominant factors affecting society in choosing leaders $39.16 \%$, political factors $30.83 \%$, social factors $29.16 \%$, and cultural factors $10.83 \%$.

Then the implementation of an open meeting campaign, distribution of basic foodstuffs, assistance to the community added to the confidence of the respondent community in choosing. According to the respondents, voters still need to do this. The answers of respondents to the above questions reached $50-60 \%$,

Meanwhile, the responses of respondents varied about whether the electoral system was good and running well and produced the best leaders. Respondents who voted for presidential candidate number 01 answered that it was good $40 \%$. Respondents who said that our electoral system needed to improve the system $36.66 \%$. Then $23.33 \%$ of respondents answered that our electoral system was not going well.

Likewise with the question, whether the election administrators are truly transparent, honest, fair, and independent without government intervention. Most of the respondents answered that the election organizer was really transparent, honest, fair, and independent without government intervention. $58.33 \%$ answered 'doubt' $26.66 \%$, the answer 'no' was $15 \%$. 
Material factors, finance, and wealth of candidates, including the main factors in winning the pair of candidates in each election event, $36.66 \%$. Respondents who answered that it was not the financial factor (wealth) that caused the election victory at $35.83 \%$. The rest of the finance / wealth is not necessarily a victory for $27.5 \%$ of respondents.

\section{Conclusion}

From the analysis conducted, the researchers concluded that the communication patterns carried out by the Jokowi-MA campaign team in North Sumatra were using direct communication patterns and direct communication.

Direct communication is carried out by visiting the community directly, visiting community leaders, and religious leaders such as clerics, scholars, preachers, and social figures. Conducting meetings with voters, hands-on operation presidential candidates to crowded places, and door-to-door visits or meetings conducted by the winning team or volunteer teams.

The 'indirect' pattern of communication means communication made with the use of mass media, both conventional mass media (media media) and alternative media (social media), including the use of outdoor media, such as the installation of banners, billboards, billboards, t-shirts, marches, and Because the media is considered important, there is a special team provided by the campaign team to manage the media.

Social media as the most frequently used media such as online media, fecebooks, twitters, WA groups are used to build a good image in the eyes of the public and influence voter behavior. The messages conveyed are related to work programs that have been carried out and the perfection of further work programs.

Management of the campaign team for the Jokowi-Ma'ruf regional campaign team in North Sumatra along with all winning teams or volunteers to plan communication strategies to win. Campaign team management includes regional mapping, consolidation of the campaign team with supporting parties and winning teams, approaching religious leaders and delivery of the presidential candidate work program to the voting community.

By conducting survey and mapping the areas know which bases, which areas are weak and which areas should be improved. The North Sumatra region is mapped into two regions, namely the West Coast region and the East Coast region.

The East Coast region such as Medan, Langkat, Binjai, Asahan, Labuhan Batu, Tabagsel, and other areas are predominantly Muslim. To win Muslim votes, a communication approach was carried out to religious figures such as ustad and ulama and this area was a priority for the campaign team.

In the West Coast region such as Karo, Simalungun, Siantar, Tapanuli Nias, and others, the tendency of voters to support the presidential candidates is that the campaign team's approach is not a priority.

Jokowi-MA's regional campaign teams (TKD) are located in 32 city districts in North Sumatra to consolidate to strengthen ranks and unity. The provincial campaign team together with the district city campaign team together with 9 supporting parties and volunteer teams carried out 'consolidation' both internally and externally. Each party and the candidate from the supporting party carried out a campaign, in addition to the pileg campaign, the presidential candidate campaign was also carried out.

The approach of religious figures' such as recitation groups, officers, pesantren, and others including Alwasliyah and Muhammadiyah mass organizations was carried out. Meanwhile, NU organizations clearly support it because the vice president of Ma'ruf Amin is a NU administrator. 
Apart from the campaign team, the winning team or the volunteer team also approached the voting community. In accordance with the field, character, and work program of each volunteer. Like the volunteer "Jamila" the target is Muslim mothers. Then Volunteer Ma'ruf Amin, specifically approaching Muslim voters. $80 \%$ of volunteers are general in nature, $15 \%$ are religious and $5 \%$ are sectoral such as farmers, fishermen, women, and others.

Various "work programs" and accomplishments are exposed to serve as political marketing. Of course, many policies have been launched to attract and influence voter behavior. The work program that was delivered gave hope for better development such as free education and health, pre-work cards, smart cards, and toll road infrastructure development.

The regional campaign team describes the president's vision and mission and work program. Then local issues are adjusted to regencies / cities in North Sumatra such as agrarian issues, labor issues, the construction of the Medan-Tebingtinggi toll road, the construction of the Pematang Siantar toll road, and Binjai and others.

The response of the Jokowi-Ma'ruf presidential candidate to the strategy of the presidential campaign team in North Sumatra is based on the tabulation of respondents' answers in North Sumatra, generally the respondents answered that the campaign team's hands-on operation activity and the presidential candidates increased the influence or confidence of the voters of their chosen presidential candidate. Likewise, the delivery of the presidential candidate's work program on toll road infrastructure development and campaigns using outdoor media such as billboards.

Then the campaign by approaching and involving religious leaders, clerics, clerics, preachers, and others is considered to attract the sympathy of the voters. Candidates for Jokowi-Ma'ruf Amin are the candidates who campaign most often compared to the presidential candidate pair Prabowo-Sandi. Respondents' answers to each of the question items above reached $70-80 \%$.

This is the case with the voters' response to the Jokowi-Ma'ruf 'presidential candidate' in North Sumatra. Generally, respondents choose because of the figure of a presidential candidate, work programs such as toll road infrastructure development. Then the presidential candidate has the ability to lead the country, Ma'ruf Amin's position as vice president influences or increases the electability of the Muslim community and the incumbent factor is a factor in the victory of the presidential candidate. Respondents' answers to each of the question items above were quite high, reaching the range of $70-90 \%$.

Next, an open meeting campaign for the distribution of basic food aid to the community increased the public's confidence in choosing. Respondents considered such a campaign still necessary. Community satisfaction with the performance of the presidential candidate of choice. The impression 'sharing of positions in the cabinet does not hinder government performance. Respondents' answers to each of the above question items reached $50-69 \%$.

The electoral system is already good and running well and produces the best leaders $36.66 \%$. Election organizers are truly transparent, honest, fair, and independent without government intervention: 58.33\%, "Doubtful": 26.66\%, and answered "No": 15\%. Then the candidate wealth factor including the main factor of victory for the candidate pair is $36.66 \%$.

From the tabulation of the total votes acquired by the presidential candidates from regencies / cities in North Sumatra, the pair number 01 Jokowi-Ma'ruf is superior to their rivals with the acquisition of: $3,838,749(52.16 \%)$ votes, his rival pair number 02 PrabowoSandi received 3,520 .846 (47.84\%) votes.

For the entire East Coast, the Prabowo-Sandi pair was superior with total votes: 3,168,384 (59.22\%) and Jokowi-MA: 2,181,838 (40.78\%) votes. For this region, the vote acquisition is a thin difference for the City of Medan and the regencies / cities that are close 
to Medan City, but far from Medan City areas such as Labuhan Batu, Tabagsel, the difference in the defeat of Jokowi-MA votes is getting more and more severe. In contrast, for the entire region The West Coast pair Jokowi-MA won hands down with the acquisition of: 1,656,911 $(82.46 \%)$ votes and Prabowo-Sandi: 352,462 (17.54\%) votes.

\section{References}

Hasil Rekapitulasi KPU Sumut, Jokowi - Ma'ruf Raih 52,32 Persen, dalam https://www.liputan6.com/pilpres/read/3970756/hasil-rekapitulasi-kpu-sumut-jokowi maruf-raih-5232-persen

Iryadi, I. et al. (2019). Muslim and Democracy: A Reflection from 2012 Aceh's Gubernatorial Election. Budapest International Research and Critics Institute-Journal (BIRCI-Journal). P. 545-555

Jokowi-JK Pada Pemilihan Presiden 2014, Fakultas Ilmu Komunikasi Universitas Prof. Dr. Moestopo (Beragama), Jurnal Print ISSN:1412-7873; Online ISSN: 2598-7402, tahun 2017.

Katadata.co.id, Rebutan Suara Ulama Demi Gaet Suara Muslim Di Pilpres 2019.

Kompas.com, KPU Tetapkan Jokowi Ma'ruf dan Prabowo-Sandi Sebagai Capres dan Wapres.

Kompas.com, KPU Tetapkan Jokowi Ma'ruf dan Prabowo-Sandi Sebagai Capres dan Wapres. https://infopemilu.kpu.go.id.

Novita Damayanti dan Radja Erland Hamzah, Strategi Kampanye Politik Pasangan

Prasetyo, G. et al. (2020). Modern Paradigm: Democratic Skills in a Higher Order Thinking Skills Frame. Budapest International Research and Critics Institute-Journal (BIRCIJournal). P. 150-159

Real Count KPU Pilpres 2019 dalam https://www.bisnis.com/real-count-kpu.

Rozaili and Zulfikar. (2020). Youth Perception of Legislative General Elections in Pidie

Regency. Budapest International Research and Critics Institute-Journal (BIRCIJournal). P. 1262-1269

Wawanacara Sekretaris Tim Kampanye Daerah (TKD) Jokowi-Ma'ruf Amin Provinsi

Sumatera Utara, Dr. Sutarto, MSi, tanggal 7 Mei 2020.

Wawanacara Direktur Tim Relawan Jokowi-MA Provinsi Sumatera Utara, Agus Marwan tanggal 30 Mei 2020.

Angket penelitian 